\title{
ПУТЬ В «ЦАРСТВО ПРАВА И СПРАВЕДЛИВОСТИ
}

Г.М. Даниленко*

Когда Организация Объединенных Наций объявляла последнюю декаду этого тысячелетия Декадой международного права, она исходила из того, что в новом тысячелетии по крайней мере отношения государств должны строиться на нормах международного права. Это, конечно, господство права международных отношений. Идея эта - не новая. Она занимала умы теоретиков и практиков международного права.

Уже в ранних документах Организации Объединенных Наций эта идея тоже провозглашалась. Иногда интересно посмотреть на некоторые документы, которые были приняты на первых этапах деятельности Организации, особенно это полезно сделать в наши дни, когда отмечается 50-летие ООН. Если мы посмотрим на проект Декларации прав и обязанностей государств, который был принят Комиссией международного права ООН на ее первой сессии, то есть в 1949 году, то там содержатся довольно интересные положения, хоторые и сегодня звучат чрезвычайно актуально.

В проекте Декларации, в частности, говорится о том, что государства мира образуют сообшество, управляемое международным правом. Сушественным элементом реализации основной цели $\mathrm{OOH}$ - поддержания международного мира и безопасности - является установление господства права и справедливости. В русском переводе «рейнгл» это даже не господство права и справедливости, а царство права и справедливости.

Проект Декларации устанавливал также, что каждое государство обязано поддерживать свои отношения с другими государствами на основах принципа, согласно которому суверенитет каждого государства подчинен верховенству международного права.

Все это звучит очень современно. Я думаю, что на данном этапе достаточно широкую поддержку получила идея, что верховенства права в международных отношениях невозможно достичь в тех условиях, когда государства заключают между собой договоры, принимает определенные нормы. И в то же время эти нормы действуют только в межгосударственных отношениях и никак не влияют на поведение субъектов национального права.

* Руководитель Центра международного права ИГП РАН. Публикация подготовлена на основе его выступления на международной конференции «50 лет ООН и международное право». 
Идея заключается в том, что эффективная имплементация международного права возможна только в условиях, когда государство эффективно имплементирует нормы международного права на внутреннем уровне.

На этой теме я хотел остановиться более подробно, в частности рассмотреть вопрос о вкладе России в этот процесс. Думаю, что инициатива России на мехдународном уровне, инициатива России в рамках $\mathrm{OOH}$, в частности инициатива о созыве новой конференции, - это очень хорошо и полезно.

Россия может внести вклад в эффективную имплементацию международного права, прежде всего реформируя свою правовую систему, строя правовое государство. И как элемент строительства правового государства - осушествление эффективной имплементации норм мехдународного права, прежде всего норм в области прав человека, на своей собственной территории.

Россия сделала здесь колоссальный шаг вперед по сравнению с тем, что существовало во времена Советского Союза. Все знают, что советская система права была практически закрытой. Международные договоры применялись в исключительных ситуациях, когда конкретные законодательные ахты содержали прямые отсылки $\mathrm{K}$ договорам.

Новая Конституция России открыла внутреннюю систему прямому влиянию мехдународного права. Все мы знаем ст. 15 и важные положения, хоторые в ней содержатся. В связи со ст. 15 возникают несколько очень сушественных вопросов.

Первый вопрос заключается в том, насколько эффективна сама по себе ст. 15, насколько эффективен принцип, который в ней заложен. Мы знаем примеры из международной практики, когда в конституции государства содержится очень хорошая статья, провозглашающая принципы и нормы международного права частью права страны или только договоры - частью права страны.

Декларация остается декларацией. На практику национального применения она не оказывает влияния. Франция в данном случае один из примеров, когда в течение долгого времени постепенно эта идея имплементации мехдународных договоров воплотилась во французскую конституцию, а затем и в практику. Какова же ситуация в России?

С широких позиций многое будет зависеть от политических процессов в России. Естественно, если страна открывается внешнему миру и положения ст. 15 приняты на этой волне, то страна, открытая внешнему миру, пытается имплементировать стандарты, принятые в международном соошестве, в своем внутреннем законодательстве. Это одна ситуация. 
Ежели мы говорим о стране, которая имеет это очень хорошо звучащее конституционное положение, но тем не менее отгораживается от внешнего мира, когда доминируют какие-то националистические подходы, думаю, что такая статья может остаться просто декларацией. Поэтому с этих широких позиций, думаю, многое зависит от политических процессов в России.

Многое зависит также от позиции судов, от того, как суды относятся $\mathrm{K}$ этой статье, действительно ли они на практике признают международное право частью права страны, как они трактуют конкретные вопросы в этой области. Много, наконец, зависит от образования. Речь идет о том, чтобы адвокаты, практикующие юристы знали о том, что эта статья должна работать, чтобы они в своих конкретных аргументациях, например перед судебными или административными органами, могли ссылаться на положения этой статьи, то есть этот момент нельзя упускать. Российская ассоциация международного права должна очень активно работать в этой области.

Хотел бы остановиться на практике судов на данный момент. Действительно, какова пэзиция российских судов в этом вопросе? Думаю, что это чрезвычайно важно. Могу констатировать, что позиция судов изменилась под влиянием новой Конституции и некоторых положений международного права, взятых из предыдущей Конституции. И действительно, мы можем констатировать, что суды уже смотрят на ст. 15, суды применяют эту статью и есть ряд чрезвычайно интересных дел, прежде всего Конституционного Суда, который ссылался на нормы международного права в ряде решений. Есть также определенная подвижка в позиции Верховного Суда России. Приведу один пример. Верховный Суд России уже применял нормы международного права в ряде конкретных решений, но знаменательным является постановление Пленума Верховного Суда 1994 года о судебной практике проверки законности и обоснованности ареста и продления срока содержания под стражей. Вы знаете значение постановлений Пленума Верховного Суда, руководяшие разъяснения Пленума. Практически они являются источником права, и любой практикующий юрист, обратившись в самый низший суд и процитировав постановление Пленума, естественно, усилит свою позицию, сделает ее очень убедительной для любого судьи в России.

Так вот, данное постановление прямо предписываст нижестоящим судам применять конкретную норму международного права, норму, которая содержится в Пакте о правах человека (ст. 9), норму, которая отсутствует в российском законодательстве.

О чем идет речь? Речь идет о том, что в соответствии с УПК РСФСР, все еще действующим (и неизвестно, когда новый УПК 
будет принят), предусматривается судебный контроль только за заключением под стражу в качестве меры пресечения. А в то же время в соответствии со ст. 9 первого Пакта о правах человека о гражданских и политических правах - любой, кто лишен свободы вследствие ареста или содержания под стражей, имеет право на разбирательство его дела в суде. И Верховный Суд, сославшись на ст. 15 Конституции, прямо предписал нижестоящим судам принимать жалобы, в том числе на ситуации, связанные с арестом, и рассматривать законность и обоснованность ареста, не только задержание и заключение под стражу, но и содержание в форме ареста. Думаю, что это очень интересный пример.

В отношении Конституционного Суда возникает несколько весьма спорных вопросов. Если мы посмотрим на ст. 15 , то первый вопрос - это, конечно, широта ст. 15. В российскую правовую систему входят не только договоры, не только обшепризнанные принципы или общее международное право, как в некоторых странах, но и то и другое. В этом плане российская правовая система действительно стала очень открытой. К сожалению, ст. 15 говорит о договорах Российской Федерации, употрябляется такая формулировка: не договоры , ратифицированные Российской Федерацией, а договоры Российской Федерации. И более того, как вы знаете, ст. 15 провозглашен приоритет договоров Российской Федерации по отношению $\mathrm{K}$ противоречашим им нормам внутреннего законодательства. В этой ситуации возможна достаточно сложная проблема, когда договоры, не ратифицированные Верховным Советом (теоретически, по крайней мере, эта ситуация была) или не ратифицированные Думой, Федеральным Собранием на данный момент, могли превалировать над нормами закона, принятыми, скахем, старым Верховным Советом или на данный момент - Федеральным Собранием. Таким образом, нарушались бы определенные принципы правотворчества, когда акты, принимаемые какими-либо министерствами или Министерством иностранных дел, пакты международного характера превалировали бы над законами, которые приняты Федеральным Собранием. Эта проблема существовала, но на данный момент она устранена. Думаю, что она устранена очень удачно. Устранена новым Законом о международных договорах Российской Федерации. В соответствии с этим законом любой международный договор Российской Федерации, который устанавливает правила, противоречащие внутреннему законодательству, или правила, которые требуют принятия правил внутреннего законодательства, подлежат обязательной ратификации Федеральным Собранием. Я считаю, что это очень удачное положение, которое включено в российский Закон о мехдународных договорах. 
Второй вопрос возник в практике Конституционного Суда. Это вопрос о том что такое общепризнанные принципы и нормы международного права и что такое договоры Российской Федерации. Думаю, что эти понятия смешивать не стоит. В ином случае просто не имело бы смысла в Конституции употреблять две различные формулировки. Иногда у нас и в литературе, и в практике Конституционного Суда говорилось о том, что то или иное положение российского законодательства противоречит обшепризнанным принципам и нормам международного права, и после этого сразу цитировался конкретный договор, который обязывает Российскую Федерацию. Полагаю, на данном уровне происходит просто смешение этих двух понятий. Думаю, когда мы говорим об общепризнанных принципах и нормах международного права - формулировка, которая на международном уровне практически не употребляется, мы все-таки имеем в виду так называемое обшее международное право, прежде всего общее международное публичное право.

В связи с этим возникают, конечно, серьезные проблемы для судов, которые не имеют практики применения норм международного права. Как установить общепризнанные принципы и нормы мехдународного права? В отношении договоров ситуация, конечно, проще, можно найти какой-то текст договора, установить, ратифицирован ли он Российской Федерацией, были ли сделаны оговорки К этому договору Российской Федерацией, то есть установить правовую норму. Но даже в этой области, к сожалению, скажем, Конституционный Суд не всегда адекватно, по моему мнению, подходил к применению договора, хотя, может быть, это просто недостатки редактирования решения. В решениях можно найти довольно странные вещи, когда делаются ссылки на конкретный международный договор и не говорится о том, ратифицирован ли он Российской Федерацией. Говорится, например, о том, что Пакт о правах человека принят только Генеральной Ассамблеей $\mathrm{OOH}$, и точка. Или, скажем, в одном из последних постановлений о Законе Чувашской Республики о выборах Государственного совета Чувашской Республики говорится о том, что действие Международного пакта о гражданских и политических правах признано Российской Федерацией.

Вы знаете, конечно, что Венская конвенция о праве международных договоров не содержит такого термина, речь идет о ратификации, принятии, утверждении, присоединении и т.д., но не о признании действия международного договора. Как я сказал, в отношении договоров ситуация проше. В отношении обшепризнанных принципов и норм международного права ситуация сложнее. Действительно, нельзя ожидать от судов, в том числе и от Конституционного Суда, несмотря на то что там известные юристы-меж- 
дународники, что Конституционный Суд и особенно обычный суд в России знают, какова ситуация с конкретными обшепризнанными принципами и нормами международного права. Здесь требуется экспертная оценка и т.д. Тем более, что просто так, как это иногда делается, в частности, Конституционным Судом, когда говорят: бшепризнанные принципы и нормы международного права. После этого цитируется резолюция Генеральной Ассамблеи, может быть, один договор, и считается, что наличие такой нормы уже доказано. Я думаю, что это очень проблематичный подход. Конечно, психологически легко понять, В частности, судей Конституционного Суда, когда они берут конкретную резолюцию, конкретный договор, а потом говорят, что это общепризнанный принцип, и приводят его в качестве доказательства.

В действительности же, если вы посмотрите, как следует доказывать норму международного права, прежде всего обычную норму международного права, как это делает, например, Международный Суд ООН, надо исследовать не только международные документы, но и практику государств в той или иной области, позицию конкретного государства по данной проблеме. Это, конечно, очень сложно делать, но это делать придется.

Я думаю, дाя наших судов также важно учитывать позицию России, в том числе по общепризнанным принципам и нормам международного права. Одна точка зрения заключается в том, что позиция России здесь не важна, общепризнанные принципы и нормы международного права будут связывать Россию в любой ситуации, имеются ли какие-то конкретные доказательства ее согласия с этой нормой или нет. Другая позиция заключается в том, что согласие России с конкретной нормой, применимой в конкретном деле, всегда должно быть доказано, иначе такая норма не будет обязывать Россию. Еще не ясно, какая точка зрения будет превалировать, но я думаю, что последняя точка зрения найдет достаточно много сторонников в стране.

Еще одна проблема, которая возникает в практике. Она возникла уже в практике Конституционного Суда, - это проблема самоисполнимых и несамоисполнимых норм. Это весьма сложная проблема, она имеет не только техническое значение, но и более широкое, политическое значение. Опираясь на тезис о несамоисполнимости конкретных норм международного права, которые подлежат применению в том или ином деле, если эту концепцию толковать довольно широко, можно практически свести на нет значение ст. 15 Конституции. И у нас есть примеры в международном сообществе, когда конституции содержат хорошие положения, но путем чрезвычайно широкого применения концепции самоисполнимых и несамоисполнимых норм их положения практически 
сводятся на нет. Думаю, Соединенные Штаты Америки могут быть хорошим примером в этом смысле. Имеется ряд известных дел, когда эта концепция трактовалась чрезвычайно широко и таким образом договоры не применялись в конкретной ситуации, например договоры, трактующие вопросы прав человека. В этом смысле эта концепция опасна для нас.

В ситуации, когда мы пытаемся имплементировать нормы международного права внутри страны, слишком широко толковать эту концепцию чрезвычайно опасно, но тем не менее она существует, она возникает объективно. Она не возникала в советские времена, потому что никого не волновало применение международных договоров в определенном смысле внутри страны, но она объективно возникает в нашей ситуации, потому что действительно есть какие-то договоры, которые прямо во внутринациональном законодательстве применяться не могут по самым различным причинам.

Концепция самоисполнимости уже утверждена в российском законодательстве, в отношении практики судов она проблематична. Хотя эта проблема возникала в практике Конституционного Суда, но в российском законодательстве она уже утвердилась. И я не согласен с тем, что эта концепция утвердилась с принятием российского Закона о мехдународных договорах. Действительно, там содержится эта норма, но первый акт, который утвердил эту концепцию в российском законодательстве, - это, конечно, первая часть Гражданского кодекса России, который действует с начала 1995 года и принят, конечно, раньше, чем Закон о международных договорах. Статья 7 Кодекса четко говорит (практически формулировки совпадают с последующим Законом о международных договорах): есть определенные международные договоры, которые требуют принятия внутренних актов для своей имплементации, и есть договоры, которые действуют в Российской Федерации непосредственно. Это было сказано в ст. 7 Гражданского кодекса. Думаю, что практикующие юристы уже понимают эту проблему. Если вы посмотрите, например, комментарий к Гражданскому кодексу под редакцией профессора Брагинского, то там приводятся очень интересные примеры на основе Парижской конвенции о защите промышленной собственности, конкретные положения этой Конвенции, которая содержит отсылки $\mathrm{k}$ национальному праву и где говорится о том, что эти положения по этой причине не могут считаться самоисполнимыми и, соответственно, будет действовать ст. 7 Гражданского кодекса.

$\mathrm{K}$ сожалению, в практике Конституционного Суда России эта проблема не получила должного освещения, хотя она возникла уже в одном из первых дел, рассмотренных Конституционным Судом (я 
имею в виду дело о ст. 33 КЗОТ). В этом деле Суд сослался на положение второго Пакта по правам человека об экономических правах и, самое главное, - на Конвенцию МОТ № 111 как на непосредственно применимое право в данной ситуации. Но если мы посмотрим на положения, на которые ссылался Суд, я думаю, очень проблематично, что они являются самоисполнимыми. Например, Конвенция МОТ № 111 содержит формулировки о том, что страны, ратифицирующие Конвенцию, проводят национальную политику посредством согласованных с национальными условиями и практикой методов. Конвенция предусматривает, что, например, запрещение дискриминации в области прекращения трудовых отношений на основании достижения пенсионного возраста (это как раз проблема в этом деле) возможно лишь на основании национального законодательства, то есть в данном случае Конвенция содержала конкретную отсылку к национальному законодательству и через национальное законодательство положения Конвенции могли трансформироваться во внутреннее право.

Весьма проблематично считать, что такая Конвенция будет самоисполнимой или конкретные положения этой Конвеции будут самоисполнимы.

Перед тем как закончить, я хотел бы отметить проблему иерархии норм, остановиться очень кратко на проблеме иерархии норм международного права и российского права. Я думаю, ситуация более или менее ясна в отношении договоров, особенно она стала ясна в отношении договоров, когда новый Закон о мехдународных договорах внес эту поправку, или может быть уточнение, о котором я уже упомянул. Ситуация прояснилась.

А вот в отношении обшепризнанных принципов и норм международного права вопрос остается спорным. Статья 15 провозглашает приоритет только норм международного договора, она не провозглашает приоритет общепризнанных принципов и норм международного права по отношению к внутреннему законодательству. В то же время в Конституции есть ст. 17, которая говорит, что права и свободы человека и грахданина Российской Федерации признаются и гарантируются согласно общепризнанным принципам и нормам мехдународного права. Возникает интересный вопрос: что означает ст. 17? Можно сказать, что это вводная статья раздела о правах человека и она имеет чисто декларативный характер, характер политической декларации, не провозглашает приоритет общепризнанных принципов и норм мехдународного права?

Возможна и другая интерпретация: она провозглашает приоритет в этой конкретной ббласти отношений обшепризнанных принципов и норм международного права. Эта интерпретация очень хорошая. Она защищает права человека в большей степени, потому 
что есть определенные ошепризнанные принципы, нормы в этой области, которые не содержатся в конкретных договорах Российской Федерации. Но тем не менее я считаю, что вопрос остается отхрытым и нам нужно посмотреть, по какому пути пойдет практика судов.

Второй вопрос в этой области чрезвычайно важный, он заключается в том, что Конституция не содержит прямого положения, которое говорило бы о том, что договоры Российской Федерации блладают приоритетом по отношению не только к российским федеральным законам, но и к нормативным актам, принятым в субъектах Федерации. Этого положения в Конституции нет. И здесь возникает, конечно, масса проблем, это пробел в Конституции. Но я думаю, что этот пробел, к счастью, уже заполнен одним из важных решений Конституционного Суда России. Я думаю, что здесь вклад Конституционного Суда России весьма значителен.

В постановлении по делу о беженцах Северной Осетии Конституционный Суд (хотя это дело было вынесено на основании старой Конституции, но тем не менее провозглашенный принцип имеет значение) сказано, что ст. 2 Международного пакта о гражданских и политических правах, закрепляющая равенство граждан перед законом, в силу ст. 32 старой Конституции имеет преимушества перед законами Российской Федерации, следовательно, я цитирую, «и республик в ее составе». Это чрезвычайно важное положение в конкретном решении. Если мы посмотрим на другие решения, принятые на основе современной Конституции, то это положение так четко не выражено, но сам принцип поддерживается. Этот принцип поддерживается в постановлении о Законе Чувашской Республики о выборах Госсовета, который я уже цитировал. Думаю, постановление чрезвычайно известное и громкое, приобретшее громкую известность, - постановление о Чечне - тоже исходит именно из этого принципа.

Статья получена в апреле 1996 г. 